\title{
Interactions of Rabconnectin-3 with Cav2 calcium channels
}

\author{
Maria A. Gandini, Ivana A. Souza, Jing Fan, Katherine Li, Decheng Wang and Gerald W. Zamponi* (D)
}

\begin{abstract}
This study describes the interaction between Cav2 calcium channels and Rabconnectin-3, a di-subunit protein that is associated with synaptic vesicles. Immunostaining reveals that both Rabconnectin-3a (RB-3a) and Rabconnectin$3 \beta$ (RB-3 $\beta$ ) are colocalized in mouse hippocampal neurons. Co-immunoprecipitations from brain tissue is consistent with the formation of a protein complex between RB-3 $\alpha$ and RB-3 $\beta$ and both Cav2.2 and the related Cav2.1 calcium channel. The coexpression of either RB-3a or RB-3 $\beta$ with Cav2.2 calcium channels in tsA-201 cells led to a reduction in Cav2.2 current density without any effects on the voltage-dependence of activation or inactivation. Coexpression of both Rabconnectin-3 subunits did not cause an additive effect on current densities. Finally, the presence of Rabconnectin-3 did not interfere with $\mu$-opioid receptor mediated G $\beta \gamma$ modulation of Cav2.2 channels. Altogether, our findings show that Rabconnectin-3 has the propensity to regulate calcium entry mediated by Cav2.2 channels.
\end{abstract}

Keywords: Cav2,2 calcium channels, Rabconnectin-3, Hippocampus, N-type channels, Opioid receptor

\section{Introduction}

Cav2 channels are essential mediators of synaptic communication in the mammalian and invertebrate nervous systems $[1-5]$. Calcium entry via these channels in response to membrane depolarization leads to the release of neurotransmitters, and this process is facilitated through physical interactions of the channels with the vesicle release machinery [6-10]. Indeed, numerous synaptic proteins such as SNAP25, syntaxin 1 and synaptotagmin have been shown to bind to presynaptic calcium channels in a dynamic and often calcium-dependent manner as part of the vesicle release process [11-14]. Conversely, calcium channel activity can be substantially altered by these interactions which have been attributed to a synaptic protein interaction (a.k.a. synprint) site that is localized within the intracellular region connecting domains II and III of the pore forming Cava1 subunit [15-18].

Rabconnectin-3 is a poorly characterized synaptic protein that is formed by $\alpha$ and $\beta$ subunits, encoded respectively by DMXL2 and WDR7 [19-21]. Rabconnectin-3 $\alpha$ and- $3 \beta$ (RB-3 $\alpha$ and RB-3 $\beta$ ) belong to WD40 family of

\footnotetext{
* Correspondence: zamponi@ucalgary.ca

Department of Physiology and Pharmacology, Hotchkiss Brain Institute and Alberta Children's Hospital Research Institute, Cumming School of Medicine, University of Calgary, 3330 Hospital Dr. NW, Calgary T2N 4N1, Canada
}

proteins that contain repeats consisting of two internal dipeptide sequences, glycine-histidine and tryptophanaspartic acid [22, 23]. RB-3 $\alpha$ contains 12 WD40 domains and it is mainly recovered in the synaptic soluble fraction [19]. On the other hand RB-3 $\beta$ has 7 WD40 domains (hence the name WDR7) [20]. Very little is known about their key functional or catalytic domains, or key sites for protein-protein interactions, but it is known that WD40 domains lead to the formation of a $\beta$-propeller structure that serves as an interaction platform for a variety of proteins involved in diverse cellular processes $[22,23]$. RB-3 $\alpha$ and RB-3 $\beta$ are abundantly expressed in the brain where they are associated with synaptic vesicles [20]. They have been shown to interact with Rab3A GDP/GTP exchange proteins, and with members of the Rab3 small G protein family that are involved in the control of calcium dependent exocytosis $[19,20]$. Although the precise role of Rabconnectin-3 in modulating exocytosis has remained enigmatic, the observation that DMXL2 haplo-insufficiency or WDR7 gene deletion cause developmental delays and mental retardation suggests a critical neurophysiological function of Rabconnectin-3 [24, 25].

Here, we present evidence that RB- $3 \alpha$ and RB-3 $\beta$ form a molecular complex with Cav2.1 and Cav2.2 channels in mouse brain. Furthermore, we show that both subunits 
affect Cav2.2 current density, suggesting that Rabconnectin-3 may contribute to regulating brain function via alteration of presynaptic calcium influx.

\section{Results and discussion}

We first examined the co-localization of Rabcconnectin-3 subunits with Cav2.2 calcium channels expressed endogenously in cultured mouse hippocampal neurons (10 days in vitro). Fig. 1a shows confocal images obtained from hippocampal neurons labelled with anti-RB-3 $\beta$ (green) and anti-Cav2.2 $\alpha 1$ (red), revealing that both proteins are diffusely distributed in soma, axons and dendrites from neighboring cells with numerous overlapping puncta. RB-3 $\alpha$ (red) and Cav2.2 (green) were also found to be expressed in the same neurons (Fig. 1b). Next, we performed co-immunoprecipitations between Cav2.2 channels, RB- $3 \beta$ and RB- $3 \alpha$ using mouse brain homogenate. As shown in Fig. 1c, immunoprecipitation with Cav2.1 and Cav2.2 antibodies and Western blot analysis with an RB-3 $\beta$ antibody resulted in a band near the expected size of $163 \mathrm{kDa}$. Immunoprecipitation with an RB$3 \beta$ antibody allowed us to detect RB-3 $\alpha$ (Fig. $1 d, 340 \mathrm{kDa}$ band) and the reverse experiment also confirmed that the two Rabconnectin-3 subunits are in a complex (Fig. 1e).
Consequently, using an RB-3 $\alpha$ antibody, Cav2.2 channels could be immunoprecipitated (Fig. 1f). These data provide evidence that Cav2.2 channels and Rabconnectin-3 form a macromolecular protein complex, and are consistent with the immunostaining experiment.

To ascertain whether Rabconnectin-3 can alter Cav2.2 channel function, we recorded whole cell barium currents through recombinant $\operatorname{Cav} 2.2\left(+\operatorname{Cav} \beta_{1 \mathrm{~b}}+\operatorname{Cav\alpha }_{2} \delta-1\right)$ channels expressed in tsA-201 cells in the absence or presence of Rabconnectin-3. Representative whole-cell Cav2.2 current recordings are shown in Fig. 2a. Figure 2b shows the average current density-voltage relationships (peak current amplitude normalized by $\mathrm{Cm}$ ) in response to membrane depolarizations from a holding potential $(\mathrm{Vh})$ of $-80 \mathrm{mV}$. The expression of either RB-3 $\alpha$ or RB$3 \beta$ significantly reduced the current density across a wide range of voltages and this is also reflected in a decrease in Gmax (Fig. 2c) We did not observe changes in voltage for half-maximal activation (Fig. $2 \mathrm{~b}$ inset) and the slope factor (not shown). Neither Rabconectin-3 subunit had any significant effect on half-inactivation potential (Fig. 2d). Rabconnectin-3 is a cytoplasmic protein that, as we show here, appears to interact with Cav2.2 channels. When we transfected just the pore

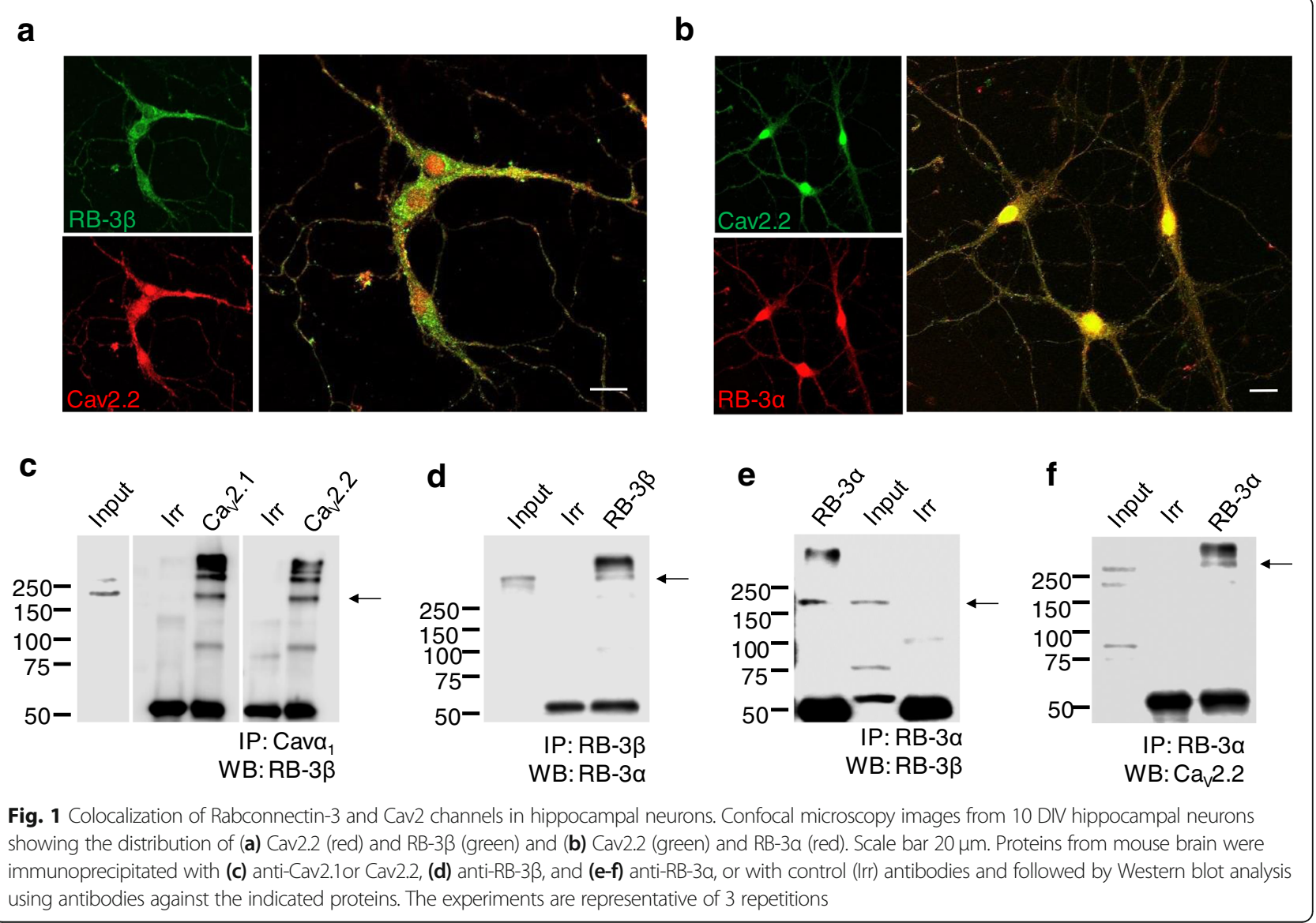




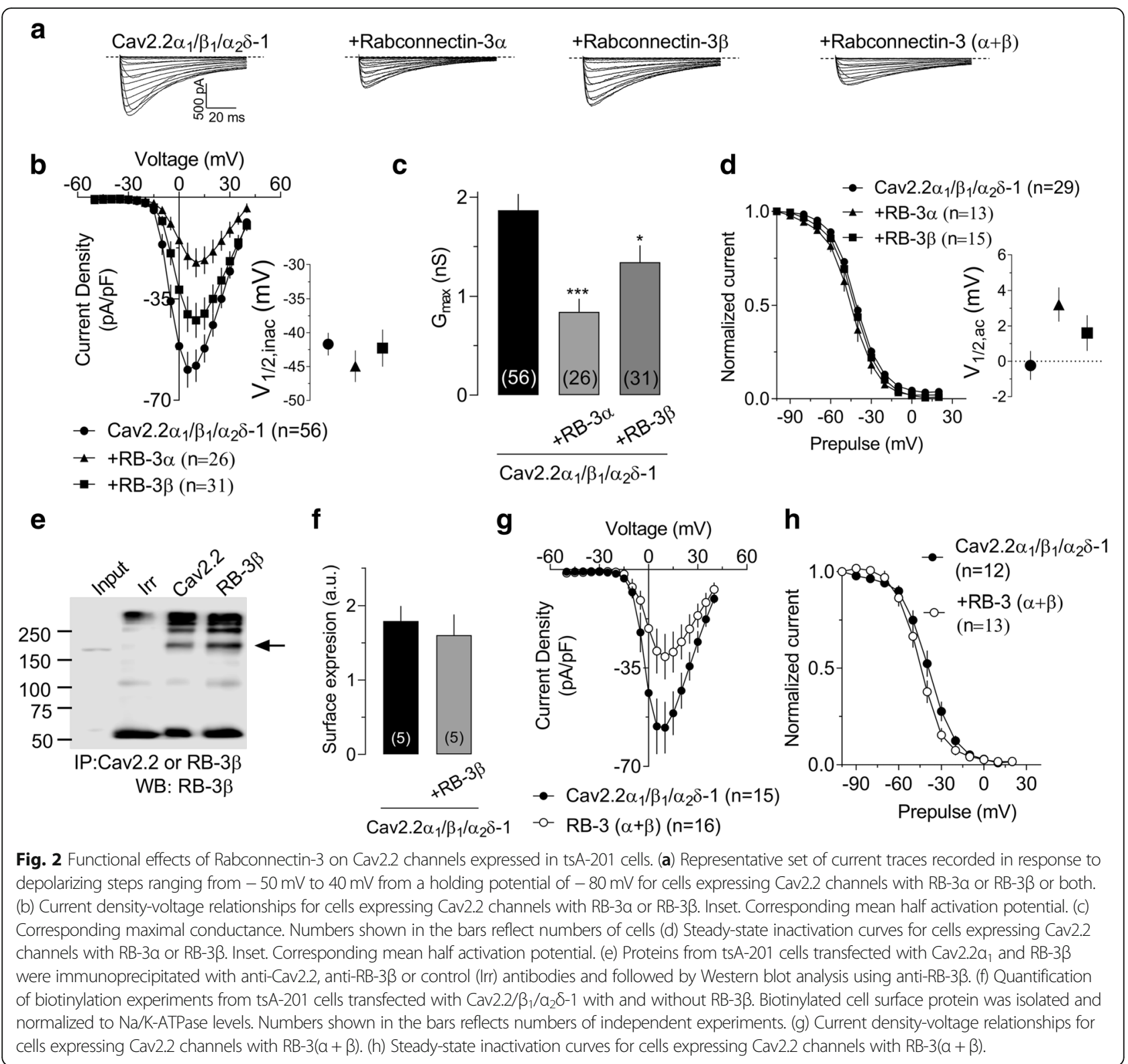

forming Cav2.2 $\alpha_{1}$ subunit with RB-3 $\beta$ and performed a co-immunoprecipitation we found an interaction between these proteins (Fig. 2e). This means that the ancillary $\operatorname{Cav} \beta$ subunit is not necessary for forming the molecular complex. Interestingly, biotinylation experiments from cells expressing RB-3 $\beta$ and Cav2.2 channels did not reveal any difference in cell surface expression (Fig. 2f), suggesting that the decrease in current density is not due a reduction in the number of channels at the plasma membrane. Coexpression of both Rabconnectin3 subunits produced effects that were similar to those observed in the presence of RB- $3 \alpha$ (Fig. $2 g$ and h), indicating that there are no synergistic effects (current density at $10 \mathrm{mV}$ in $\mathrm{pA} / \mathrm{pF}-\mathrm{Cav} 2.2 / \beta_{1} / \alpha_{2} \delta-1$ : control $58.06 \pm 5.6 ; \quad+\mathrm{RB}-3 \alpha: 22.02 \pm 5.0 ; \quad+\mathrm{RB}-3 \beta ; \quad-42.35 \pm 6.1$;
Cav2.2/ $\beta_{1} / \alpha_{2} \delta-1: \quad$ control $-56.27 \pm 9.0 ; \quad+\mathrm{RB}-3(\alpha+\beta)$ : $-30.95 \pm 8.1 ; P>0.05$ compared to RB-3 $\alpha$ ), and that the formation of a complete Rabconnectin-3 complex is still capable of modulating Cav2.2 current density.

Given the bulky nature of Rabconnectin-3, we wondered if its presence might affect regulation of the channels by $\mathrm{G}$ protein $\beta \gamma$ subunits which are known to target the N-terminus and domain I-II linker regions of Cav2.2 [26-30]. This was tested by coexpressing $\mu$-opioid receptors with the channel along with RB- $3 \alpha$ plus RB-3 $\beta$, and then activating the receptors via DAMGO application (Fig. 3a). We found no difference in receptor mediated Cav2.2 channel inhibition (Fig. 3b), nor in the relief of this inhibition via strong voltage pulses (Fig. 3c). Hence, $\mathrm{G}$ proteins retain access to their binding site on the 


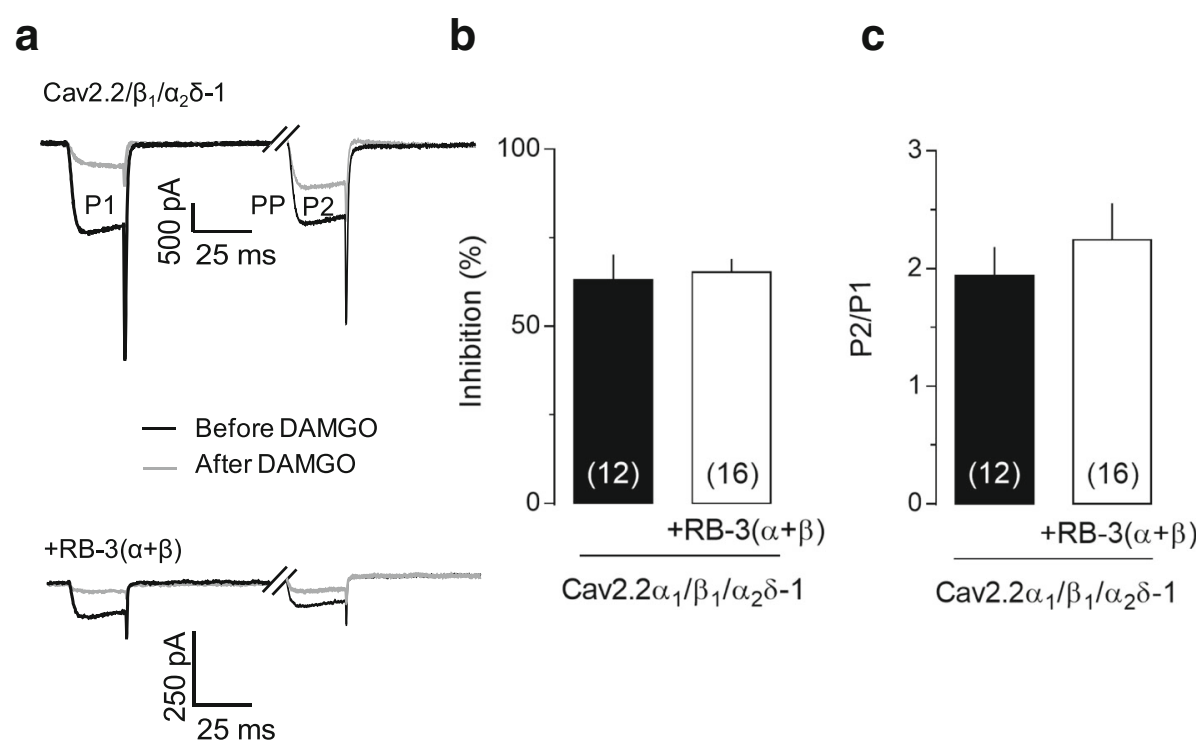

Fig. 3 Lack of effect of Rabconnectin-3 on G protein modulation of Cav2.2. (a) Representative set of Cav2.2 currents recorded before or after the application of $10 \mu \mathrm{M}$ DAMGO. As noted in the Methods section, the first current in each trace is evoked by a test depolarization to $+10 \mathrm{mV}(\mathrm{P} 1)$, the second inward current in a given trace is evoked by a $10 \mathrm{mV}$ test depolarization (P2) that is preceded by a strong depolarizing prepulse (PP, note that the prepulse-evoked outward current has been blanked out). The increase in current amplitude seen during P2 in the presence of DAMGO reflects prepulse relief of GBY modulation. (b) Percentage of peak current inhibition (during P1) of Cav2.2 currents after application of $10 \mu M$ DAMGO in the presence of absence of RB-3 $(a+\beta)$. (c) Voltage dependent pre-pulse facilitation measured in the presence of DAMGO. The bars reflect the current evoked by test pulse P2 normalized to the current evoked by test pulse P1. This experiment was performed either in the presence or the absence of RB-3( $a+\beta)$. Numbers in parentheses reflect numbers of cells.

Cav2.2 channels, suggesting that the Rabconnectin-3

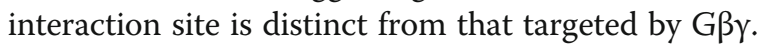

At this point we do not know where on the channel the Rabconnectin-3 interaction site is located, and whether the interaction is direct, or mediated via an adaptor protein. It is interesting to note that both Rabconnectin-3 subunits independently produced a reduction in current density, which may suggest that there are two separate interaction sites for these two subunits, or that they both target the same region, and in such a manner that the functional effects are preserved when both subunits are present. It is interesting to note that RB-3 $\beta$ was less effective in reducing current densities

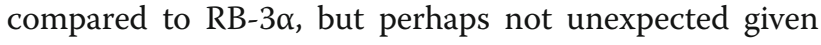
that these two proteins show considerable differences in their numbers of WD40 repeats. We also do not know whether the reduction in current density is due a reduction in single channel amplitude or in maximum open probability. It will also be interesting to determine whether Rabconnectin-3 can interfere with the modulation of channel activity by synaptic proteins targeting the synprint site $[7,8,31,32]$.

We reiterate that the importance of a fully functional Rabconnectin-3 protein is important for brain health. Tata and colleagues [25] described a case of three brothers with an in-frame deletion in the RB- $3 \alpha$ encoding gene (DMXL2). This resulted in reduced RB-3 $\alpha$ mRNA levels and manifested itself as a series of neurodevelopmental disorders such as mental retardation, dysregulation of the hypothalamus-pituitary hormonal axis and metabolic disorders such as diabetes and hypoglycemia. On the other hand, it has been shown that low DMXL2 expression in mice causes abnormal dendritic development. DMXL2+/- mice show differences in corpus callosum neuroanatomy compared to wild type animals [25]. Along these lines, Chen and co-workers [33] linked an $\mathrm{RB}-3 \alpha$ missense variant to nonsyndromic hearing loss. Altogether, this strongly suggests that RB- $3 \alpha$ is a key regulator in neuronal and homeostatic processes. RB-3 $\beta$ is deleted along with the TXNL1 gene in a condition termed 18q syndrome, a condition characterized by mental retardation that varies in severity from patient to patient, along with a wide array of anatomical and physiological abnormalities, including dystonia [24, 34]. It is unlikely that all these phenotypic abnormalities are mediated through alterations of Cav2.2 channel activity. That being said, our experiments in tsA-201 cells would be consistent with a gain of Cav2.2 channel function. In this context, it is interesting to note that a gain of Cav2.2 channel function through a missense mutation has been associated with dystonia [35].

In summary, we present the first description of a physical and functional interaction between Rabconnectin-3 and Cav2.2 calcium channels. This interaction adds to a 
list of many synaptic proteins that associate with this important presynaptic calcium channel.

\section{Materials and methods cDNAs}

Wild type rat calcium channel subunit cDNAs were donated by Dr. Terry Snutch (University of British Columbia, Vancouver, BC) and subcloned into pcDNA3.1 vectors. Human WDR7 cDNA was purchased from Thermo Scientific and human DMXL2 cDNA was obtained from Origene ${ }^{\mathrm{Tx}}$.

\section{cDNA transfection}

After splitting and seeding to 50\% confluence, tsA-201 cells were transfected with $3 \mu \mathrm{g}$ of each plasmid encoding Cav2.2 $\alpha 1$, Cav $\beta 1$ and Cav $\alpha 2 \delta$-1, respectively, in the presence or absence of WDR7, DMXL2 or both cDNAs. In addition, $0.5 \mu \mathrm{g}$ of cDNA encoding green fluorescent protein was added to the transfection mixture to identify and select transfected cells. For $\mathrm{G}$ protein studies $3 \mu \mathrm{g}$ of the $\mu$-opioid receptor cDNA were added. Cells used for electrophysiology experiments were moved to $30^{\circ} \mathrm{C}$ after transfection, whereas those used for Western blotting were maintained at $37^{\circ} \mathrm{C}$.

\section{Patch clamp recordings}

Electrophysiological recordings were performed using whole cell patch-clamp at room temperature $\left(22-24^{\circ} \mathrm{C}\right)$. Currents were recorded using an Axopatch 200B amplifier linked to a computer with pCLAMP9.2 software. The external recording solution contained (in $\mathrm{mM}$ ): $5 \mathrm{BaCl}_{2}, 10$ TEA-Cl, $1 \mathrm{MgCl}, 128 \mathrm{NaCl}, 5 \mathrm{KCl}, 10$ HEPES and 10 glucose ( $\mathrm{pH}$ 7.4). Patch pipettes were filled with a solution containing (in mM) $110 \mathrm{CsCl}, 2.5 \mathrm{MgCl}, 10$ EGTA, 10 HEPES, 3 ATP, and 0.5 GTP (pH 7.4). Current densities were obtained by dividing peak current by the whole cell capacitance. Current density-voltage relationships were generated from the peak current obtained during $250 \mathrm{~ms}$ pulses between -50 to +40 in $5 \mathrm{mV}$ increments from a holding potential of $-80 \mathrm{mV}$. Steady-state inactivation was measured by applying $2 \mathrm{~s}$ conditioning pulses from 100 to $+20 \mathrm{mV}$ in $10 \mathrm{mV}$ increments followed by a $100-$ ms test pulse to $+10 \mathrm{mV}$. I-V relationships were fitted with a Boltzmann equation of the form: $\mathrm{I}=\mathrm{Gmax}^{*}(\mathrm{Vm}-$ $\mathrm{Vr}) /(1+\exp .(-(\mathrm{Vm}-\mathrm{V} 1 / 2 \mathrm{act}) / \mathrm{k}))$, where $\mathrm{I}$ is the peak current, $\mathrm{Vm}$ is the membrane voltage, $\mathrm{V} 1 / 2$ act is the half activation potential, $\mathrm{Vr}$ is the reversal potential, and $\mathrm{k}$ is the slope factor. Steady-state inactivation curves were fitted with the equation: I/Imax $=1 /(1+\exp .((\mathrm{Vp}-\mathrm{V} 1 /$ 2inac)/k)), where $I / I$ max is the normalized peak current, $\mathrm{Vp}$ is the conditioning pre-pulse, V1/2inac is the halfinactivation potential and $\mathrm{k}$ is the slope factor.

$G$ protein modulation induced by $\mu$-opioid receptor activation was assessed as described by us previously [36]. In brief, the extent of total $\mathrm{G}$ protein inhibition was assessed by a multi pulse protocol in which cells are held at -80 $\mathrm{mV}$. Currents are evoked by a $25 \mathrm{~ms}$ test depolarization to $+10 \mathrm{mV}$ (P1), followed by a $500 \mathrm{~ms}$ repolarization to -80 $\mathrm{mV}$. Subsequently, a strong $50 \mathrm{~ms}$ depolarizing pulse to + $100 \mathrm{mV}$ is applied (which causes a reversal of G $\beta \gamma$ mediated voltage-dependent inhibition, see [37]). This is followed by $5 \mathrm{~ms}$ repolarization and then a second test pulse to $+10 \mathrm{mV}$ (P2). Total G protein inhibition is determined by monitoring the DAMGO-induced reduction in peak current amplitude during P1. Voltage-dependent G protein modulation is determined by the extent of prepulse relief of inhibition as assessed by calculating the ratio of current amplitudes observed during P2 and P1 in the presence of receptor agonist.

\section{Co-immunoprecipitation assays and western blots}

Cells were detached from culture dishes, washed with phosphate-buffered saline, and lysed in single-detergent lysis buffer (50 mM Tris-Cl, $150 \mathrm{mM} \mathrm{NaCl,} 1 \%$ Triton X100, and Complete 1×; Roche Applied Science). Protein concentration was determined using the Bradford assay. Rat brain proteins were lysed in RIPA buffer ( $25 \mathrm{mM}$ Tris$\mathrm{HCl}$ (pH 7.6), $150 \mathrm{mM} \mathrm{NaCl}, 1 \% \mathrm{NP}-40,1 \%$ sodium deoxycholate, $0.1 \%$ SDS, and Complete $1 \times$ ). Fifty micrograms of protein samples were boiled for $5 \mathrm{~min}$ in protein-loading buffer (1.7\% SDS, 0.1 M 2-mercaptoethanol, 5\% glycerol, $58 \mathrm{mM}$ Tris-Cl, and $0.002 \%$ bromophenol blue, $\mathrm{pH} 6.8$ ). Co-immunoprecipitation assays were performed using rat brain proteins or lysates from transfected tsA-293 cells. One milligram of proteins was incubated with $3 \mu \mathrm{g}$ of specific or irrelevant (as an isotype control) antibodies. Immune complexes were resolved in $8-15 \%$ SDSpolyacrylamide gels and transferred to nitrocellulose membranes then immunoblotted using the following antibodies: Cav2.1(1:500; Alomone ACC-001), Cav2.2 (1:500; Alomone ACC-002), WDR7 (1:1000; Santa Cruz sc-85,210), and DMXL2 (1:500; Novus Biological NBP1-93618).

\section{Cell surface biotinylation}

Transfected cells were washed with ice-cold HEPESbased saline solution (HBSS) and incubated on ice for $15 \mathrm{~min}$ to stop trafficking of proteins. Surface proteins were biotinylated for $1 \mathrm{~h}$ on ice with $1 \mathrm{mg} / \mathrm{ml}$ of EZLink Sulfo-NHS-SS-Biotin (Thermo Scientific). The reaction was quenched with $100 \mathrm{mM}$ glycine for $15 \mathrm{~min}$, and cells were lysed in modified RIPA buffer (in mM: 50 Tris, $150 \mathrm{NaCl}, 5$ EDTA, 1\% Triton X-100, 1\% NP-40, $0.2 \%$ SDS, pH 7.4) for $45 \mathrm{~min}$. Protein quantification was performed using a Bio-Rad protein assay dye, and $2 \mathrm{mg}$ of lysates was incubated with $100 \mu \mathrm{l}$ of Neutravidin beads (Thermo Scientific) for $1.5 \mathrm{~h}$ at $4{ }^{\circ} \mathrm{C}$. Beads were washed three times with lysis buffer and proteins eluted with $2 \times$ Laemmli sample buffer. Biotinylated proteins and lysates were resolved by SDS-PAGE and analyzed by 
western blot using anti-Cav2.2 (1:500, ACC-002 Alomone) and 1/5000 anti-Na/K-ATPase (1:5000, AB 7671 Abcam) antibodies. For each experiment, background was subtracted and integrated density of bands was measured and normalized to the $\mathrm{Na} / \mathrm{K}$-ATPase signal as loading control.

\section{Immunostaining}

Hippocampal neurons (10 DIV) were blocked for $1 \mathrm{~h}$ with $0.5 \% \mathrm{BSA}+10 \% \mathrm{NGS}+0.3 \%$ Triton $\mathrm{X}-100$ in $1 \mathrm{X}$ PBS. Sections were then incubated with the following antibodies: Cav2.2 (1:100; Alomone ACC-002 or 1:100; Synaptic systems 152,311), WDR7 (1:100; Santa Cruz sc85,210) and DMXL2 (1:100, Santa Cruz sc-162,739) overnight at $4{ }^{\circ} \mathrm{C}$. Neurons were washed 3 times with PBS before incubation with the following secondary antibodies: anti-rabbit (Alexa Fluor 488, 1:1000, Invitrogen A21206), anti-mouse (Alexa Fluor 633, 1:500, Invitrogen A21050) and anti-goat (Alexa Fluor 633, 1:1000, Invitrogen A11055) for $1 \mathrm{~h}$ at room temperature. Images were taken using a Zeiss LSM 510 confocal microscope.

\section{Statistics}

All error bars reflect standard errors. Statistical analysis was conducted with Student's t-tests. Significance was set at 0.05 . Asterisks denote significance as follows: * $p<0.05,{ }^{* * *} p<0.01,{ }^{* * * *} p<0.001$.

\section{Abbreviations}

RB-3: Rabconnectin-3; SNAP25: Synaptosome Associated Protein 25; WD: Tryptophan-aspartic acid

\section{Acknowledgments}

The authors thank Lina Chen for technical support.

\section{Author contributions}

MAG designed the study and drafted the manuscript. GWZ supervised the study and co-wrote the manuscript. MAG, IAS, DW, JF, and KL performed experiments and data analysis. All authors read and approved the final manuscript'

\section{Funding}

This work was supported by a grant to GWZ from the Natural Sciences and Engineering Research Council (NSERC). GWZ holds a Canada Research Chair. MAG is supported by Alberta Innovates and a Fellowship from the Canadian Institutes of Health Research. KL and DW both held summer studentship awards from Alberta Innovates and NSERC. JF held a Chen Fong studentship from the Hotchkiss Brain Institute.

\section{Availability of data and materials}

The data used in our study are available from the authors on reasonable request.

\section{Ethics approval and consent to participate}

All experiments were conducted in accordance with the policies of the University of Calgary Animal Care Committee.

\section{Consent for publication}

Not applicable.

\section{Competing interests}

The authors declare that they have no competing interests.
Received: 22 May 2019 Accepted: 17 June 2019

Published online: 28 June 2019

\section{References}

1. Spafford JD, Munno DW, Van Nierop P, Feng ZP, Jarvis SE, Gallin WJ, Smit AB, Zamponi GW, Syed NI. Calcium channel structural determinants of synaptic transmission between identified invertebrate neurons. J Biol Chem. 2003;278:4258-67. https://doi.org/10.1074/jbc.M211076200.

2. Catterall WA. Voltage-gated calcium channels. Cold Spring Harb Perspect Biol. 2011;3:a003947. https://doi.org/10.1101/cshperspect.a003947.

3. Simms BA, Zamponi GW. Neuronal voltage-gated calcium channels: structure, function, and dysfunction. Neuron. 2014;82:24-45. https://doi.org/ 10.1016/j.neuron.2014.03.016.

4. Ackermann F, Waites CL, Garner CC. Presynaptic active zones in invertebrates and vertebrates. EMBO Rep. 2015;16:923-38. https://doi.org/10. 15252/embr.201540434.

5. Mochida S. Presynaptic calcium channels. Int J Mol Sci. 2019;20. https://doi. org/10.3390/jims20092217

6. Khanna R, Li Q, Bewersdorf J, Stanley EF. The presynaptic CaV2.2 channeltransmitter release site core complex. Eur J Neurosci. 2007:26:547-59. https://doi.org/10.1111/j.1460-9568.2007.05680.x.

7. Sudhof TC. Calcium control of neurotransmitter release. Cold Spring Harb Perspect Biol. 2012;4:a011353. https://doi.org/10.1101/cshperspect.a011353.

8. Wong FK, Li Q, Stanley EF. Synaptic vesicle capture by CaV2.2 calcium channels. Front Cell Neurosci. 2013;7:101. https:/doi.org/10.3389/fncel.2013.00101.

9. Glebov OO, Jackson RE, Winterflood CM, Owen DM, Barker EA, Doherty P, Ewers $\mathrm{H}$, Burrone J. Nanoscale structural plasticity of the active zone matrix modulates presynaptic function. Cell Rep. 2017;18:2715-28. https://doi.org/ 10.1016/j.celrep.2017.02.064.

10. Williams CL, Smith SM. Calcium dependence of spontaneous neurotransmitter release. J Neurosci Res. 2018;96:335-47. https://doi.org/10. 1002/jnr.24116.

11. Sheng $\mathrm{ZH}$, Yokoyama $\mathrm{CT}$, Catterall WA. Interaction of the synprint site of $\mathrm{N}$ type $\mathrm{Ca} 2+$ channels with the C2B domain of synaptotagmin I. Proc Natl Acad Sci U S A. 1997:94:5405-10. https://doi.org/10.1073/pnas.94.10.5405.

12. Khanna R, Zougman A, Stanley EF. A proteomic screen for presynaptic terminal N-type calcium channel (CaV2.2) binding partners. J Biochem Mol Biol. 2007;40:302-14

13. Condliffe SB, Corradini I, Pozzi D, Verderio C, Matteoli M. Endogenous SNAP-25 regulates native voltage-gated calcium channels in glutamatergic neurons. J Biol Chem. 2010;285:24968-76. https://doi.org/10.1074/jbc.M110.145813.

14. He R, Zhang J, Yu Y, Jizi L, Wang W, Li M. New insights into interactions of presynaptic Calcium Channel subtypes and SNARE proteins in neurotransmitter release. Front Mol Neurosci. 2018;11:213. https://doi.org/10 3389/fnmol.2018.00213.

15. Rettig J, Sheng ZH, Kim DK, Hodson CD, Snutch TP, Catterall WA. Isoformspecific interaction of the alpha1 A subunits of brain $\mathrm{Ca} 2+$ channels with the presynaptic proteins syntaxin and SNAP-25. Proc Natl Acad Sci U S A. 1996; 93:7363-8. https://doi.org/10.1073/pnas.93.14.7363.

16. Keith RK, Poage RE, Yokoyama CT, Catterall WA, Meriney SD. Bidirectional modulation of transmitter release by calcium channel/syntaxin interactions in vivo. J Neurosci. 2007;27:265-9. https://doi.org/10.1523/JNEUROSCl.421306.2007.

17. Toft-Bertelsen TL, Ziomkiewicz I, Houy S, Pinheiro PS, Sorensen JB. Regulation of $\mathrm{Ca} 2+$ channels by SNAP-25 via recruitment of syntaxin-1 from plasma membrane clusters. Mol Biol Cell. 2016;27:3329-41. https://doi.org/ 10.1091/mbc.E16-03-0184.

18. Chai Z, Wang C, Huang R, Wang Y, Zhang X, Wu Q, Wang Y, Wu X, Zheng L, Zhang C, Guo W, Xiong W, Ding J, Zhu F, Zhou Z. CaV2.2 gates calciumindependent but voltage-dependent secretion in mammalian sensory neurons. Neuron. 2017;96:1317-1326.e1314. https://doi.org/10.1016/j.neuron. 2017.10.028

19. Nagano F, Kawabe H, Nakanishi H, Shinohara M, Deguchi-Tawarada M, Takeuchi M, Sasaki T, Takai Y. Rabconnectin-3, a novel protein that binds both GDP/GTP exchange protein and GTPase-activating protein for Rab3 small G protein family. J Biol Chem. 2002;277:9629-32. https://doi.org/10. 1074/jbc.C100730200.

20. Kawabe H, Sakisaka T, Yasumi M, Shingai T, Izumi G, Nagano F, DeguchiTawarada M, Takeuchi M, Nakanishi H, Takai Y. A novel rabconnectin-3binding protein that directly binds a GDP/GTP exchange protein for Rab3A 
small G protein implicated in ca(2+)-dependent exocytosis of neurotransmitter. Genes Cells. 2003:8:537-46.

21. Sakisaka T, Takai Y. Purification and properties of rabconnectin-3. Methods Enzymol. 2005;403:401-7. https://doi.org/10.1016/S0076-6879(05)03035-1.

22. Xu C, Min J. Structure and function of WD40 domain proteins. Protein Cell. 2011;2:202-14. https://doi.org/10.1007/s13238-011-1018-1.

23. Jain BP, Pandey S. WD40 repeat proteins: Signalling scaffold with diverse functions. Protein J. 2018;37:391-406. https://doi.org/10.1007/s10930-0189785-7.

24. van Diepen MM, Gijsbers AC, Bosch CA, Oudesluys-Murphy AM, Ruivenkamp CA, Biilsma EK. A $797 \mathrm{~kb}$ de novo deletion of 18q21.31 in a patient with speech delay, mental retardation, sleeping problems, facial dysmorphism, and feet anomalies. Eur J Med Genet. 2011;54:86-8. https://doi.org/10.1016/ j.ejmg.2010.09.003.

25. Tata B, Huijbregts L, Jacquier S, Csaba Z, Genin E, Meyer V, Leka S, Dupont J, Charles P, Chevenne D, Carel JC, Leger J, de Roux N. Haploinsufficiency of Dmxl2, encoding a synaptic protein, causes infertility associated with a loss of GnRH neurons in mouse. PLoS Biol. 2014;12:e1001952. https://doi.org/10. 1371/journal.pbio.1001952.

26. Patil PG, de Leon M, Reed RR, Dubel S, Snutch TP, Yue DT. Elementary events underlying voltage-dependent G-protein inhibition of N-type calcium channels. Biophys J. 1996;71:2509-21. https://doi.org/10.1016/ S0006-3495(96)79444-4.

27. Herlitze S, Hockerman GH, Scheuer T, Catterall WA. Molecular determinants of inactivation and $\mathrm{G}$ protein modulation in the intracellular loop connecting domains I and II of the calcium channel alpha1 A subunit. Proc Natl Acad Sci U S A. 1997;94:1512-6. https://doi.org/10.1073/pnas.94.4.1512.

28. De Waard M, Liu H, Walker D, Scott VE, Gurnett CA, Campbell KP. Direct binding of G-protein betagamma complex to voltage-dependent calcium channels. Nature. 1997;385:446-50. https://doi.org/10.1038/385446a0

29. Findeisen F and Minor DL, Jr. Disruption of the IS6-AID linker affects voltage-gated calcium channel inactivation and facilitation. J Gen Physiol 2009;133:327-343. doi: https://doi.org/10.1085/jgp.200810143.

30. Zamponi GW, Currie KP. Regulation of ca( $) 2$ calcium channels by $\mathrm{G}$ protein coupled receptors. Biochim Biophys Acta. 2013;1828:1629-43. https://doi. org/10.1016/j.bbamem.2012.10.004.

31. Zamponi GW. Regulation of presynaptic calcium channels by synaptic proteins. J Pharmacol Sci. 2003;92:79-83.

32. Neely A, Hidalgo P. Structure-function of proteins interacting with the alpha1 pore-forming subunit of high-voltage-activated calcium channels. Front Physiol. 2014;5:209. https://doi.org/10.3389/fphys.2014.00209.

33. Chen DY, Liu XF, Lin XJ, Zhang D, Chai YC, Yu DH, Sun CL, Wang XL, Zhu WD, Chen Y, Sun LH, Wang XW, Shi FX, Huang ZW, Yang T, Wu H. A dominant variant in DMXL2 is linked to nonsyndromic hearing loss. Genet Med. 2017;19:553-8. https://doi.org/10.1038/gim.2016.142.

34. Gordon MF, Bressman S, Brin MF, de Leon D, Warburton D, Yeboa K, Fahn S. Dystonia in a patient with deletion of 18q. Mov Disord. 1995;10:496-9. https://doi.org/10.1002/mds.870100415.

35. Groen JL, Andrade A, Ritz K, Jalalzadeh H, Haagmans M, Bradley TE, Jongejan A, Verbeek DS, Nurnberg P, Denome S, Hennekam RC, Lipscombe $D$, Baas F, Tijssen MA. CACNA1B mutation is linked to unique myoclonusdystonia syndrome. Hum Mol Genet. 2015;24:987-93. https://doi.org/10. 1093/hmg/ddu513.

36. Kisilevsky AE, Mulligan SJ, Altier C, Iftinca MC, Varela D, Tai C, Chen L, Hameed S, Hamid J, Macvicar BA, Zamponi GW. D1 receptors physically interact with $\mathrm{N}$-type calcium channels to regulate channel distribution and dendritic calcium entry. Neuron. 2008;58:557-70. https://doi.org/10.1016/j. neuron.2008.03.002.

37. Zamponi GW, Snutch TP. Decay of prepulse facilitation of $\mathrm{N}$ type calcium channels during $\mathrm{G}$ protein inhibition is consistent with binding of a single Gbeta subunit. Proc Natl Acad Sci U S A. 1998;95:4035-9. https://doi.org/10. 1073/pnas.95.7.4035.

\section{Publisher's Note}

Springer Nature remains neutral with regard to jurisdictional claims in published maps and institutional affiliations.

\section{Ready to submit your research? Choose BMC and benefit from}

- fast, convenient online submission

- thorough peer review by experienced researchers in your field

- rapid publication on acceptance

- support for research data, including large and complex data types

- gold Open Access which fosters wider collaboration and increased citations

- maximum visibility for your research: over $100 \mathrm{M}$ website views per year

At BMC, research is always in progress.

Learn more biomedcentral.com/submissions 